\title{
RESPONSE OF THE ESOPHAGEAL BODY TO WET AND DRY SWALLOWS IN CHAGAS' DISEASE
}

\author{
Roberto Oliveira DANTAS and Lilian Rose Otoboni APRILE
}

\begin{abstract}
Background - Wet swallows cause a greater esophageal contraction amplitude and duration than dry swallows. In Chagas' disease there is a reduction in amplitude of esophageal contraction but we do not know if the difference between wet and dry swallows is seen in the disease. Aim - To compare the esophageal contractions after wet and dry swallows in patients with Chagas' disease. Methods - We measured the area under the curve (amplitude $\mathrm{x}$ duration) of the esophageal contractions in 30 patients with a diagnosis of esophageal involvement by Chagas' disease and 44 controls. We used the manometric method with continuous perfusion. The contractions were measured at 2, 7 , 12 and $17 \mathrm{~cm}$ below the upper esophageal sphincter, after five swallows of a $5 \mathrm{~mL}$ bolus of water alternated with five dry swallows. Results - In the control group wet swallows caused a higher area under the curve than dry swallows. There was no difference between wet and dry swallows in Chagas' disease patients, and there was no difference in wet and dry swallows in Chagas' disease patients compared with dry swallows of controls. At 12 and $17 \mathrm{~cm}$ from the upper esophageal sphincter the area under the curve after wet and dry swallows in Chagas' disease patients younger than 60 years $(\mathrm{n}=15)$ was higher than in Chagas' disease patients older than 60 years $(\mathrm{n}=15)$. Conclusion - We conclude that in normal subjects there is adaptation to the presence of a liquid bolus inside the esophageal body, which does not happen in patients with Chagas' disease.
\end{abstract}

HEADINGS - Chagas disease. Deglutition. Esophageal diseases. Aging.

\section{INTRODUCTION}

Chagas' disease is the consequence of infection by the hemoflagellate protozoan Trypanosoma cruzi. The most important consequence of the infection for the esophagus is the loss of the myenteric plexus, causing esophageal motility alterations similar to those seen in esophageal idiopathic achalasia, absent or partial lower esophageal sphincter relaxation and simultaneous contractions of low amplitude in the esophageal body ${ }^{(6,7,19)}$.

The response of the esophageal body to wet swallows in healthy subjects is different from that of dry swallows ${ }^{18,14}$, ${ }^{22)}$, what may be the consequence of afferent input received by swallowing neurons ${ }^{(15)}$. The esophageal body has phasic contractions and resting muscle tone. Esophageal tone is the consequence of passive components of the esophageal wall and a neurally mediated active component. This tonic contractile activity is modulated by a cholinergic neural excitatory input ${ }^{(24)}$. The loss of this excitatory input might affect the response to wet and dry swallows.

Our hypothesis is that in Chagas' disease, as a consequence of the loss of the myenteric plexus, the esophageal response to wet swallows is similar to that of dry swallows and that the ageing process may cause further alterations of the esophageal contractions after wet and dry swallows.

\section{METHODS}

We studied 30 patients with dysphagia for solids and liquids, no regurgitation, esophageal radiologic examination with barium retention, slow transit, esophageal diameter less than $4 \mathrm{~cm}$, and a positive serologic test for Chagas' disease. Slow transit was found when the barium sulfate took more than 10 seconds to cross the esophageal body. All had an epidemiologic history of having lived in endemic areas of the disease during some time in childhood. Endoscopic examination did not detect alterations in the esophageal mucosa. The patients (13 men and 17 women aged 34 to 77 years, median 60 years) were divided into a younger group, aged 34 to 59 years, median 51 years $(n=15)$, with a duration of dysphagia of 1 to 40 years, median 5 years, and an older group aged 61 to 77 years, median 66 years $(n=15)$, with a duration of dysphagia of 1 to 60 years, median 10 years. They had not received previous treatment by pneumatic dilatation or esophagomyotomy

Departamento de Clínica Médica - Faculdade de Medicina de Ribeirão Preto - Universidade de São Paulo, Ribeirão Preto, SP, Brazil.

Correspondence: Prof. Roberto Oliveira Dantas - Departamento de Clínica Médica - Faculdade de Medicina de Ribeirão Preto, USP - $14049-900$ - Ribeirão Preto, SP, Brazil. E-mail: rodantas@fmrp.usp.br 
and were living with mild dysphagia, eating slowly soft food, and sometimes drinking water during meals. The intensity of dysphagia was similar in the two groups.

The control group consisted of 44 subjects, 11 men and 33 women, aged 18 to 78 years, median 43 years. The controls were submitted to esophageal manometry during the investigation of gastroesophageal reflux disease, and had normal esophageal endoscopic and radiologic examinations. The protocol of manometric examination was approved by the Human Research Ethics Committee of the University Hospital of Ribeirão Preto, SP, Brazil.

The manometric examination was performed with a round eight-lumen polyvinyl catheter with an outer diameter of $4.5 \mathrm{~mm}$ and an inner diameter of $0.8 \mathrm{~mm}$ (Arndorfer Specialities, Inc, Greendale, Wisconsin, USA). The four proximal lateral openings of the catheter were spaced $5 \mathrm{~cm}$ apart at $90^{\circ}$ angles. They were connected to external pressure transducers (pvb Medizintechnik Gmb H, Kirchseeon, Germany), which in turn were connected to a PC Polygraph HR (Synectics Medical, Stockholm, Sweden). The manometric signals were stored in a computer. During the manometric recordings, a minimally compliant pneumohydraulic pump (JS Biomedicals, Ventura, CA, USA) perfused distilled water at $0.5 \mathrm{~mL} / \mathrm{min}$ through each lumen.

All individuals were studied in the supine position after $12 \mathrm{~h}$ of fasting. The catheter was introduced through the nose. For the study of esophageal contractions, the catheter was positioned with the proximal opening located $2 \mathrm{~cm}$ below the upper esophageal sphincter (UES) and the other openings located at 7,12 and $17 \mathrm{~cm}$ from the UES. Five swallows of a 5-mL bolus of water alternated with five dry swallows were performed with an interval of at least 20 seconds between the successive swallows.

Using the computer Polygram Upper GI software version 6.4 (Gastrosoft, Stockholm, Sweden), we measured the area under the curve (AUC) of the contractions, which represents amplitude $\mathrm{x}$ duration (Figure 1).

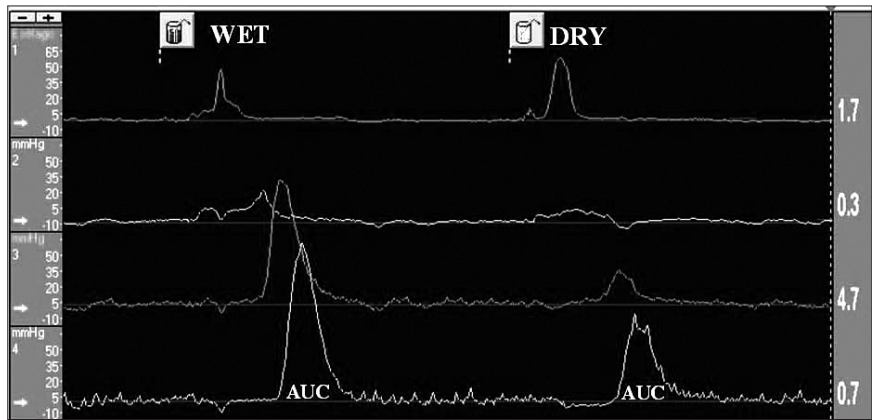

FIGURE 1. Esophageal contractions after wet and dry swallows of a control subject, showing the area under the curve (AUC). The measurement was performed at 2 (1), 7 (2), 12 (3) and $17 \mathrm{~cm}$ (4) below the upper esophageal sphincter

Data were analyzed statistically by the Kruskal-Wallis and Mann-Whitney tests. The results are reported as mean \pm SEM and median.

\section{RESULTS}

The AUC of the contractions in controls was higher after wet swallows than after dry swallows (Table 1). There was no difference between contractions after dry swallows in controls and contractions after wet and dry swallows in patients with Chagas' disease. There was also no significant difference between the contractions after wet and dry swallows in Chagas' disease. At 12 and $17 \mathrm{~cm}$ from the UES, the contractions after wet swallows had a greater area in controls than in Chagas' disease patients (Figure 2).

Younger and older patients with Chagas' disease did not have differences in contractions when comparing wet and dry swallows (Table 2). At 12 and $17 \mathrm{~cm}$ from the UES, the contractions after wet and dry swallows had higher AUC in younger patients than in older patients (Figure 3).

TABLE 1 . Area under the curve of esophageal contractions measured at 2, 7,12 and $17 \mathrm{~cm}$ from the upper esophageal sphincter, after wet and dry swallows in patients with Chagas' disease $(\mathrm{n}=30)$ and controls $(\mathrm{n}=44)(\mathrm{mm} \mathrm{Hg} \mathrm{x} \mathrm{s})$

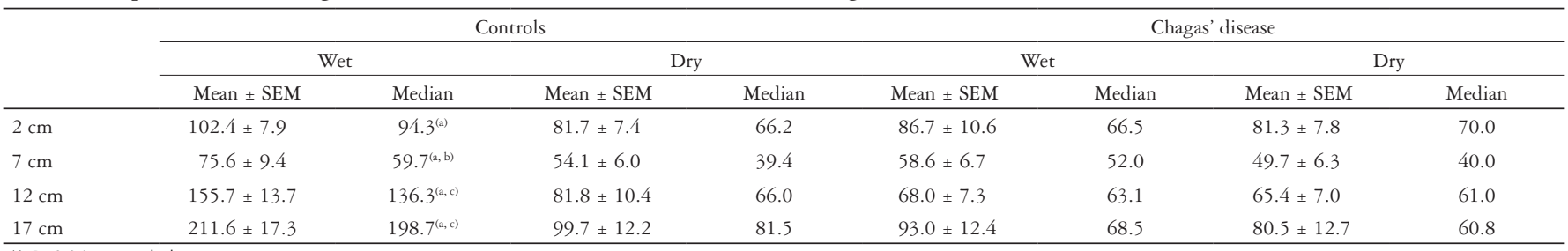

$P<0.04$ vs controls dry

(b): $P<0.02$ vs Chagas dry
(c): $P<0.01$ vs Chagas wet and dry

TABLE 2. Area under the curve of esophageal contractions measured at 2, 7, 12 and $17 \mathrm{~cm}$ from the upper esophageal sphincter, after wet and dry swallows in patients with Chagas' disease younger than 60 years $(\mathrm{n}=15)$ and older than 60 years $(\mathrm{n}=15)(\mathrm{mm} \mathrm{Hg} \mathrm{x} \mathrm{s})$

\begin{tabular}{|c|c|c|c|c|c|c|c|c|}
\hline & \multicolumn{4}{|c|}{ Younger } & \multicolumn{4}{|c|}{ Older } \\
\hline & \multicolumn{2}{|c|}{ Wet } & \multicolumn{2}{|c|}{ Dry } & \multicolumn{2}{|c|}{ Wet } & \multicolumn{2}{|c|}{ Dry } \\
\hline & Mean \pm SEM & Median & Mean \pm SEM & Median & Mean \pm SEM & Median & Mean \pm SEM & Median \\
\hline $2 \mathrm{~cm}$ & $101.6 \pm 17.8$ & 82.7 & $79.0 \pm 9.6$ & 69.8 & $71.8 \pm 10.9$ & 62.5 & $83.6 \pm 12.7$ & 70.1 \\
\hline $7 \mathrm{~cm}$ & $64.6 \pm 10.6$ & $52.0^{(a)}$ & $60.7 \pm 10.7$ & 55.5 & $51.7 \pm 7.3$ & 50.3 & $40.3 \pm 5.1$ & 36.4 \\
\hline $12 \mathrm{~cm}$ & $86.1 \pm 11.3$ & $76.9^{(\mathrm{b})}$ & $84.2 \pm 9.2$ & $78.0^{(\mathrm{b})}$ & $49.8 \pm 6.6$ & 56.2 & $48.1 \pm 8.2$ & 42.1 \\
\hline $17 \mathrm{~cm}$ & $121.6 \pm 20.4$ & $128.6^{(b)}$ & $111.3 \pm 20,9$ & $92.2^{(\mathrm{b})}$ & $64.3 \pm 9.8$ & 59.7 & $47.4 \pm 6.3$ & 40.6 \\
\hline
\end{tabular}




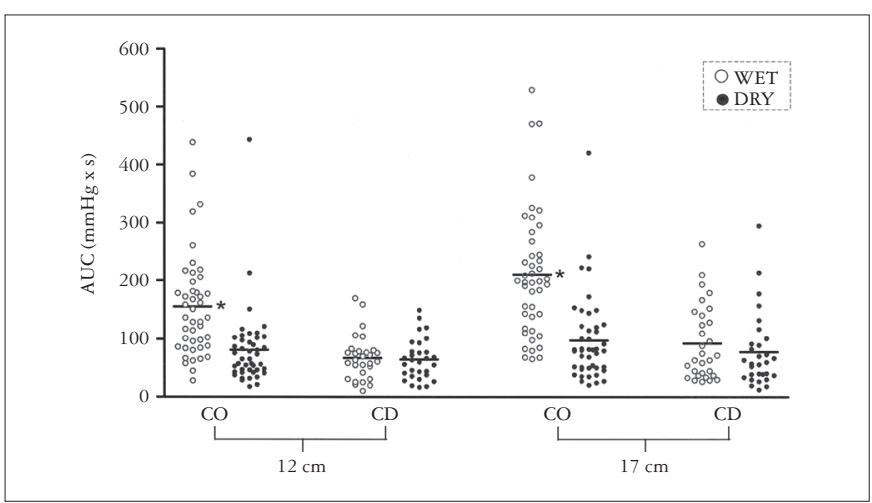

FIGURE 2. Area under the curve (AUC) of the esophageal contractions of patients with Chagas' disease $(C D, n=30)$ and control subjects $(C O, n=44)$ after wet and dry swallows, measured at 12 and $17 \mathrm{~cm}$ from the upper esophageal sphincter. The horizontal bars represent the means. ${ }^{*} P<0.05$ vs control dry and Chagas' disease wet and dry

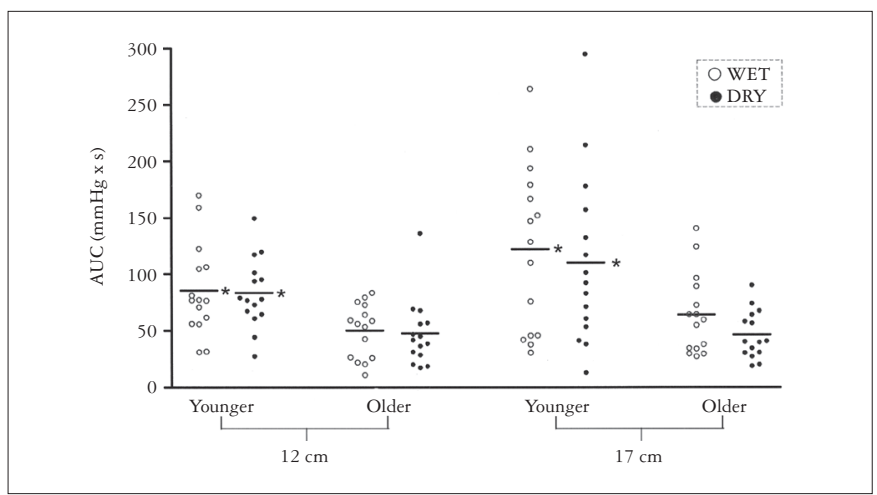

FIGURE 3. Area under the curve (AUC) of the esophageal contractions of patients with Chagas' disease younger than 60 years $(n=15)$ and older than 60 years $(n=15)$ after wet and dry swallows, measured at 12 and $17 \mathrm{~cm}$ from the upper esophageal sphincter. The horizontal bars represent the means. $* P<0.05$ vs older

\section{DISCUSSION}

Wet swallows cause significantly greater esophageal contraction amplitude and duration than dry swallows ${ }^{(2,8,14,21,22)}$. We have shown that in patients with esophageal involvement by Chagas' disease wet and dry swallows caused similar esophageal contractions, which were also similar to those seen with dry swallows in the control group. In the distal esophageal body, younger patients with Chagas' disease had a higher contraction complex than older patients after wet and dry swallows, all with an esophageal diameter of less than $4 \mathrm{~cm}$.

The swallowing neurons of the central nervous system receive sensory information from pharyngeal and esophageal receptors. The central program may be modified by peripheral afferents that adjust the motor sequence to the size of the swallowed bolus ${ }^{(15)}$. The different response to wet and dry swallows is regulated by afferent information from the esophagus ${ }^{(14)}$ that comes mainly from the distal esophagus, with possible regional differences in esophageal stretch receptors ${ }^{(8)}$. Some primary afferent neurons are considered to be located in the myenteric plexus and to innervate sensory receptors in the mucosa ${ }^{(12)}$. Impairment of esophageal stretch and sensory receptors has been suggested to occur in Chagas' disease ${ }^{(10)}$. Balloon distension inside the esophageal body showed a significantly higher esophageal compliance when compared to controls, and a need for a greater intraballoon volume to cause chest pain ${ }^{(10)}$.

A low resting tone is present in the esophageal body, which might modulate the progression of a bolus through the stomach or the proximal extent of gastroesophageal reflux ${ }^{(24)}$. This esophageal tone may be absent in Chagas' disease. The strength and propagation of phasic peristaltic esophageal contraction depend on neural and myogenic properties and a critical balanced interaction between a cholinergic excitatory system and a nitrergic inhibitory system ${ }^{(24)}$. Normal subjects have an esophageal tone that has a cholinergic component, as demonstrated by the reduction in tone by atropine ${ }^{(18)}$. In Chagas' disease, both excitatory and inhibitory innervations are impaired ${ }^{(3,6,16,19)}$.

Esophageal peristalsis does not require the presence of a bolus to support propagation through the esophagus, but with a bolus the esophageal peristalsis has a more important contraction than without a bolus. In Chagas' disease a bolus inside the esophagus does not change the contraction response. Peristaltic contraction in the smooth muscle segment of the feline esophagus is mediated via nicotinic ganglionic stimulation of postganglionic cholinergic nerves. The postganglionic release of acetylcholine stimulates esophageal smooth muscle cells via a direct action on M2 muscle receptors ${ }^{(1)}$. This innervation is at least partially lost in Chagas' disease ${ }^{(16,19)}$, causing a significant impairment of esophageal contraction ${ }^{(4,7)}$. In the lower esophageal sphincter, the cholinergically mediated component of the sphincter tone is also absent ${ }^{(5)}$. It is possible that in Chagas' disease the esophageal body does not have the capacity to change the contraction intensity with a bolus inside the organ by the impairment of the sensitivity or by the loss of the muscle capacity to increase the contraction intensity. The contraction intensity increases significantly when a cholinergic mediator (mecholyl) is given to a Chagas' disease patient with esophageal achalasia ${ }^{(19)}$, suggesting that the esophageal body is able to increase the contractions, at least with a cholinergic stimulus.

We observed a possible ageing effect on the esophageal contractions in patients with Chagas' disease. The contractions in the distal esophagus were less intense in patients older than 60 years than in patients younger than 60 years. All patients had a similar esophageal diameter, less than $4 \mathrm{~cm}$, which is considered to be grade I in our radiologic classification, without esophageal dilatation but with esophageal retention and slow transit ${ }^{(17)}$. Previous reports have shown that the ageing process alone does not decrease contraction amplitude and/or duration. HOLLIS and CASTELL ${ }^{(13)}$ found no alterations of esophageal function with ageing. RICHTER et al. ${ }^{(21)}$ found that ageing had no effect on the mean amplitude and duration of contractions elicited by dry swallows, but mean distal esophageal contractile amplitude and duration after wet swallows increased with age and peaked in the fifties. RIBEIRO et al. ${ }^{(20)}$ found that the amplitude and duration of peristalsis were similar between a group of patients older than 75 years and a group younger than 50 years. FERRIOLLI et al. ${ }^{(1)}$ also did not find differences in amplitude of contractions in normal volunteers aged $20-30$ years, $50-60$ years and $70-80$ years. The 
mean duration of contractions in the distal esophagus was longer in the 70-80 year old group than in the 20-30 year old group.

Ageing causes loss of neurons in the esophageal myenteric plexus $^{(9,16,23)}$. It is possible that in Chagas' disease patients, there is a further loss of neurons of the myenteric plexus in subjects already with some degree of reduction. In patients without an increase in esophageal diameter, there is a less intense loss of neurons compared to that seen in patients with esophageal dilatation (megaesophagus) $)^{(16)}$, a fact that may explain the possibility of further denervation. The capacity of contraction in patients with esophageal dilatation is reduced when compared with patients without esophageal dilatation ${ }^{(6)}$. In the majority of patients with Chagas' disease, the esophageal disease remained stationary for a long time before the ageing process influenced the motility ${ }^{(17)}$. The phenomenon of a decrease in the overall population of enteric neurons with ageing has been observed in various regions of the human gastrointestinal tract, with the enteric sensory neurons being particularly susceptible to neurodegeneration with age ${ }^{(7)}$.

We performed five wet and five dry swallows because previous evaluation of esophageal contractions in normal subjects and patients with Chagas' disease showed that five swallows have a similar mean amplitude and duration as 10 swallows $^{(24)}$.

In conclusion, in control subjects wet swallows cause more intense esophageal contractions than dry swallows. In Chagas' disease patients, the contractions have the same intensity with wet or dry swallows, both similar to that seen with dry swallows in control subjects. The ageing process in Chagas' disease causes further esophageal impairment after wet and dry swallows. The present results suggest that the loss of modulation of contraction by the bolus may be due to the loss of the esophageal myenteric plexus.

Dantas RO, Aprile LRO. Resposta do corpo do esôfago a deglutições de água e secas na doença de Chagas. Arq Gastroenterol. 2008;45(3):195-8.

RESUMO - Racional - Deglutições de água causam maior amplitude e duração das contrações esofágicas do que deglutições "secas". Na doença de Chagas as contrações esofágicas são de baixa amplitude e de menor duração, porém não se sabe se há diferença entre deglutições líquidas e secas. Objetivo - Comparar as contrações esofágicas após deglutições líquidas e "secas” em pacientes com doença de Chagas. Métodos - Estudou-se a área sob a curva (amplitude x duração) das contrações esofágicas em 30 pacientes com diagnóstico de esofagopatia chagásica, com diâmetro do esôfago no exame radiológico inferior a $4 \mathrm{~cm}$, e 44 controles. Utilizou-se o método manométrico com perfusão contínua. As contrações foram medidas a 2, 7, 12 e $17 \mathrm{~cm}$ distais ao esfíncter superior do esôfago, após cinco deglutições de $5 \mathrm{~mL}$ de água alternadas com cinco deglutições "secas". Resultados - No grupo controle deglutições de água provocaram maior área sob a curva do que deglutições "secas". Na doença de Chagas não houve diferença entre deglutições de água e "secas", bem como não houve diferença entre deglutições de água e "secas" nos pacientes com doença de Chagas e deglutições "secas" nos controles. A 12 e 17 cm do esfincter superior do esôfago a área sob a curva após deglutições de água e "seca", em pacientes com doença de Chagas, foi maior em pacientes com idades abaixo de 60 anos $(n=15)$ do que pacientes com idades acima de 60 anos ( $\mathrm{n}=15)$. Conclusão - Concluiu-se que em pessoas normais há adaptação à presença do bolo líquido dentro do esôfago, o que não acontece em pacientes com doença de Chagas.

DESCRITORES - Doença de Chagas. Deglutição. Esofagopatias. Envelhecimento.

\section{REFERENCES}

1. Blank EL, Greenwood B, Dodds WJ. Cholinergic control of smooth muscle peristalsis in the cat esophagus. Am J Physiol. 1989;257(Pt 1):g517-23.

2. Boesby S, Sondergaard EY, Madsen T. Oesophageal peristalsis. A simple system for the recording of oesophageal peristalsis, and the influence of bolus volume on peak peristaltic pressure amplitude. Scand J Gastroenterol. 1978;13:149-53.

3. Dantas RO, Godoy RA, Oliveira RB, Meneghelli UG, Troncon LE. Cholinergic innervation of the lower esophageal sphincter in Chagas' disease. Braz J Med Biol Res. 1987;20:527-32.

4. Dantas RO, Deghaide NH, Donadi EA. Esophageal motility of patients with Chagas' disease and idiopathic achalasia. Dig Dis Sci. 2001;46:1200-6.

5. Dantas RO. Effect of successive swallows on oesophageal motility of normal volunteers, patients with Chagas' disease and patients with idiopathic achalasia. Neurogastroenterol Motil. 2003;15:57-62.

6. Dantas RO. Comparação entre acalásia idiopática e acalásia conseqüente à doença de Chagas. Arq Gastroenterol. 2003;40:126-30.

7. Dantas RO, Aprile LR. Esophageal contractions in Chagas' disease and in idiopathic achalasia. J Clin Gastroenterol. 2005;39:863-8.

8. Dodds WJ, Hogan WJ, Reid DP, Steward ET, Arndorfer RC. A comparison between primary esophageal peristalsis following wet and dry swallows. J Appl Physiol. 1973;35:851-7.

9. Eckardt VF, LeCompte PM. Esophageal ganglia and smooth muscle in the elderly. Am J Dig Dis. 1978;23:443-8.

10. Ejima FH, Dantas RO, Simões MV, Marin Neto JA, Meneghelli UG. Intraesophageal balloon distension test in Chagas' disease patients with noncardiac chest pain. Dig Dis Sci. 1998;43 2567-71

11. Ferriolli E, Dantas RO, Oliveira RB, Braga FJ. The influence of ageing on oesophagea motility after ingestion of liquids with different viscosities. Eur J Gastroenterol Hepatol. 1996;8:793-8.

12. Gershon MD, Kirchgessner AL, Wade PR. Functional anatomy of the enteric nervous system. In: Johnson LR, editor. Physiology of the gastrointestinal tract. 3rd ed. New York: Raven Press; 1994. p.381-422.
13. Hollis JB, Castell DO. Esophageal function in elderly man. A new look at “presbyesophagus". Ann Intern Med. 1974;80:371-4.

14. Hollis JB, Castell DO. Effect of dry swallows and wet swallows of different volumes on esophageal peristalsis. J Appl Physiol. 1975;38:1161-4.

15. Jean A. Control of the central swallowing program by inputs from the peripheral receptors. A review. J Auton Nerv Syst. 1984;10:225-33.

16. Köberle F. Chagas' disease and Chagas' syndromes: the pathology of American trypanosomiasis. Adv Parasitol. 1968;6:63-116.

17. Meneghelli UG, Peria FM, Darezzo FM, Almeida FH, Rodrigues CM, Aprile LR, Dantas RO. Clinical, radiographic and manometric evolution of esophageal involvement by Chagas' disease. Dysphagia. 2005;20:40-5.

18. Murphy PP, Massey BT, Arndorfer RC, Hofman C, Kern M, Hogan WJ. Human esophageal tone has a cholinergic component in normal subjects and patients with achalasia. Gastroenterology. 1996;110:a721.

19. Oliveira RB, Troncon LE, Dantas RO, Meneghelli UG. Gastrointestinal manifestations of Chagas' disease. Am J Gastroenterol. 1998;93:884-9.

20. Ribeiro AC, Klingler PJ, Hinder RA, DeVault K. Esophageal manometry: a comparison of findings in younger and older patients. Am J Gastroenterol. 1998;93:706-10.

21. Richter JE, Wu WC, Johns DN, Blackwell JN, Nelson JL 3rd, Castell JA, Castell DO Esophageal manometry in 95 healthy adult volunteers. Variability of pressures with age and frequency of "abnormal" contractions. Dig Dis Sci. 1987;32:583-92.

22. Russell CO, Bright N, Buthpitiya G, Alexander L, Walton C, Whelan G. Oesophageal propulsive force and its relation to manometric pressure. Gut. 1992;33:727-32.

23. Wade PR, Cowen T. Neurodegeneration: a key factor in the ageing gut. Neurogastroenterol Motil. 2004;16 (Suppl 1):19-23.

24. Zhang X, Tack J, Janssens J, Sifrim DA. Neural regulation of tone in the oesophageal body: in vivo barostat assessment of volume-pressure relationships in the feline oesophagus. Neurogastroenterol Motil. 2004;16:13-21. 